\title{
Hijab in Hornbill Dance Costume: The Impacts of Religious Social Development in the Post-Modern Era
}

\author{
Wisjayanti ${ }^{1{ }^{*}}$ Dr. Dra Kun Setyaning Astuti, M.Pd. ${ }^{1}$ \\ ${ }^{1}$ Yogyakarta State University, Yogyakarta, Indonesia \\ *Corresponding author. Email: wisjayantidar@gmail.com
}

\begin{abstract}
This study aims to examine the use of the hijab in Hornbill dance costumes in East Kalimantan as part of the influence of social religious development in the Post-modern era. The post-modern era is an era after the modern one. Hornbill dance is originated from East Kalimantan. Being passed down through generations, this dance is a manifestation of the past. This study employed the qualitative ethnography method. The results show that the use of hijab in performing the dance is due to the influence of cultures, technology, and religion in the post-modern era.
\end{abstract}

Keywords: Dance, Hornbill, Post-Modern

\section{INTRODUCTION}

Indonesia is a country with a variety of cultural arts, including dance. Most Indonesian people believe that dance is a legacy from their ancestors. One of the dances considered as a legacy is the Hornbill dance.

Hornbill dance contains movements that resemble a flying hornbill. This dance was originally performed by several women. However, men are allowed to perform this dance. This dance is usually performed to welcome guests in a ritual or cultural event in society. Hornbill dance also called as Kanjet Lasa. In the Dayak Kenyah language, Lepo Tukung Kanjet means dance and Lasan means a spacious place [3].

Historically, according to the beliefs of the Dayak people, this dance is performed to show respect for ancestral spirits. Dayak people believe that their ancestors lived above the sky and then descended to Earth. At the time of descending to earth, the ancestors transformed into hornbills. Until now, the Dayak tribe believes that hornbills are the incarnation of their ancestors. This is what makes Hornbill dance considered sacred. However, along with time and changes in human perspective, the dance has changed in terms of costumes. One of these changes is the hijab worn by the dancers. This shows the influence of the social religious aspect that has developed in the era of postmodern society.
Post-modern is the era of free-thinking so that people perceive everything based on their belief and perspective, including the use of hijab as the dancer costume. The sacred dance has now changed by the era. The dancers as the artists believe that wearing hijab is normal although some people think that it is not in accordance with the rules of traditions. The use of hijab eliminates the essentials and main goals of creating this traditional dance.

The debate about the use of the hijab in Hornbill dances keeps on going. Everyone freely interprets the sacred and religious values using their interpretations. This is evidence of the shift in absolute truth in the modern era into relative truth in the post-modern era. Thus, the researchers are interested in investigating this problem more comprehensively.

\section{LITERATURE REVIEW}

\subsection{Traditional Dance}

In nature, the art of dance is the harmony of the elements of motion (wiraga), rhythm (wirama) and taste (wirasa) [2]. Wiraga is a dancer's movement. Wirama is related to the harmony of the movement with rhythm. Meanwhile, Wirasa is the dancers' feeling or appreciation for the dance. 
Dance is closely related to movements. It is a creation expressed in movements that have aesthetic values [1]. It also serves as the media to expressed feelings in a set of movements.

Hornbill dance as a traditional art is a manifestation of the relationship between humans and ancestral spirits or the relationship between humans and the supernatural [9]. They are closely related because Indonesian people still believe in the superstitions and the spirits of their ancestors remaining around them.

Based on this theory, traditional dance is related to idea expression, ideas, and human feelings about human relationships with ancestral spirits and the supernatural which is manifested in the form of movements with aesthetic values.

\subsection{Religiosity}

Religiosity is obviously related to religion or belief. Religiosity is belief in religious teachings shown by behaviors and perspective. Religious people believe that there is natural power above everything. Religiosity includes (1) religious beliefs, (2) religious knowledge, (3) religious behavior, (4) religious practices, and (5) socio-religious attitudes [1]. A social religious attitude is a condition that makes a human behave in accordance with religious teachings. A social religious attitude is formed gradually in accordance with someone's beliefs.

\subsection{Postmodern}

Postmodern consists of two words. Post means after and modern means present time [8]. Post-modern means something after the present or something after modernity. Postmodern tries to leave everything that exists in the modern era. Postmodern is a new era that emerged after modern times [4]. The postmodern era tries to replace the role of the previous era. It is also an era that rejects all ideas and theories that developed in the previous era [5]. It is an era that arose as a result of the turmoil of reflection on cultural change [5]. In the context of art, post-modern is defined as the absence of boundaries between art and life. [12].10 Neither rigid nor standardized ideas in modern art are no longer valid in the postmodern era. Everyone is free to express art according to their own perceptions. Based on these theories, postmodern is a new era that appears after the modern era and tries to replace all the ideas in the previous era.

\section{RESEARCH METHOD}

This study employed the qualitative ethnography method. Ethnography method is usually used to examine a culture [6]. The data collected are in the form of sentences describing the influence of social religious values in the post-modern era. The participants of this study were artists who know comprehensively about Hornbill dance. The data were collected through observations, interviews, and documentation. After the data were collected, the analysis was done through data reduction, data presentation, and conclusion drawing [7].

\section{RESULT AND DISCUSSION}

\subsection{Hornbill Dance}

Hornbill dance is one of the typical dances of the Dayak Kenyah tribe of East Kalimantan. This dance is usually performed in welcoming events and rituals. This dance is also called Kancet Lasan dance which contains philosophical values. Dayak Kenyah tribe believes that Hornbill dance is a legacy of their tribal ancestors. Their ancestors came from the sky to earth and turned into hornbills. The bird is often used in carvings and clothing motifs. It also plays a vital role in every traditional ceremony and dance. Thus, some figures interpret that Hornbill dance is performed to show respect for the spirits of the ancestors. There is also an opinion that the dance is a symbol of the migration of the Dayak Kenyah people from one place to another in the past as a group.

Based on the tradition of the Dayak tribe, at Hornbill dance could only be performed by women as they could dance gracefully representing hornbills with three basic movements, namely, Nganjat, Ngasi, and Purak barik [4]. Nganjat is a typical Dayak dance movement that represents an ivory hornbill flapping its wings. Then, Ngasi represents the birds flying. At last, Purak Barik represents how the bird moves over places.

Dancers wear traditional Dayak costumes with beads, lavung (rattan hat, decorated with patterns depending on clothes), headbands decorated with hornbill feathers or hornbill patterns, and colored beads. They also wear large earrings and necklaces made of hornbill feathers and tiger teeth (like a ring finger) tied to a finger and attached like a ring to keep it from falling when shaken. Hornbill dance costumes are shown in Figure 1. 


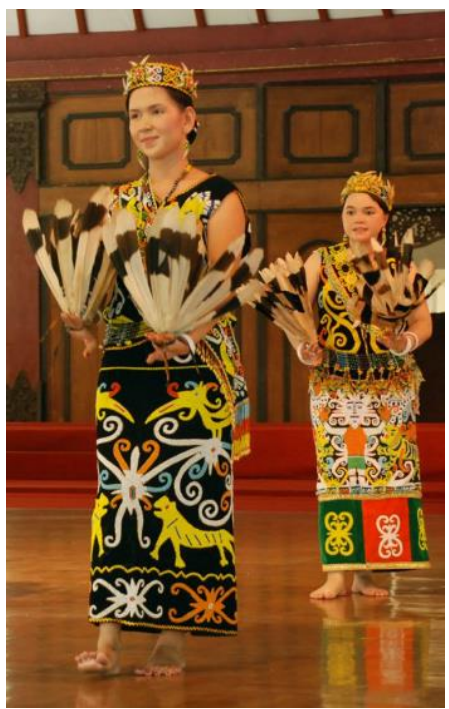

Figure 1 Hornbill dance costume [10].

At first, the Hornbill costume was very simple, but over time it changed to be more distinctive with the addition of luxurious motifs. In terms of music, the dance is accompanied by Kalimantan musical instrument called, Sape', gong, and drum. Sape' is a traditional musical instrument with strings made of Enau wood that is originated from Kalimantan. However, nowadays, people tend to use thin threads. A typical Kalimantan motif, for example hornbill is craved over Sape'. Sape' is also played in the tribe and religious rituals to praising the gods and spirits. Figure 2 below shows how Sape' looks like.

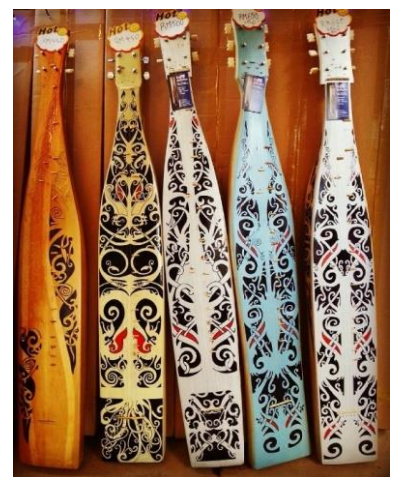

Figure 2 Sape' (Traditional Musical Instrument) [11]

\subsection{The Influence of Postmodern era on Hornbill dance}

The post-modern era is characterized by technological developments and media globalization. The globalization of the media has made a society that was previously closed begin to open up. There was a massive exchange of information from one nation to another. This exchange of information can no longer be stopped because barriers between nations seem to disappear in the current era. This mass distribution of information had unconsciously influenced the original culture of Indonesian people. Various cultures and arts have begun to transform into a better direction or have merged and then disappeared. One of the arts that have been affected is the East Kalimantan Hornbill dance.

Based on the results of this research, Hornbill dance has developed or modified from the original one. This change occurred because of the need for a tourist attraction to enrich and add to the culture of the Dayak Kenyah Tribe. This modification includes the addition of choreography and exploration of basic movements but without discarding the original Hornbill dance movements. The beauty and gracefulness are still intact.

Changes also occur in dancers. At this time the Hornbill dance is not only performed by women. Men have the same opportunity to perform the dance. In terms of costume, previously it consists of tops (inoq) and a skirt (taah). In its development, there is the addition of beads, bracelets from spun threads, shields, and Mandau or traditional Dayak weapons.

\subsection{The Use of Hijab in Hornbill Dance}

The postmodern era also influences all aspects of life, one of which is the social religious aspect. The influence of social religious changes that occur cannot be avoided, there are mass contact and mixing of culture, technology, religiosity. One of them happened in Hornbill dance. If viewed from the aspect of religiosity aspect, wearing hijab shows women's piety, and they try to keep on uphold the religious principles in daily life. However, the rules of traditional art are considered so off to date, and it needs modification and innovation. According to several figures and traditional dance experts, this is considered something that must be done in this era. The development of traditional arts in this digital era seems to be stagnant. Thus, modification and innovation are believed to be able to bring back traditional arts that are forgotten by new generations. These modifications and innovations take advantage of technology in the postmodern era. Therefore, an art that is integrated with technology, socio-culture, and socio-religious emerges. This can become a magnet for the younger generation to get to know the modified traditional arts from the past.

However, if viewed from the traditional culture perspective, there is a swift in the element of tradition. The sacred impression of a traditional art merges with external influences and seems to leave its historical value. Traditional arts are intended to enrich the dance design, but on the other hand, it eliminates the essence and sacredness of this traditional dance. Pakemtraditional dance rules that have been believed since ancient times seem to be left behind in this postmodern era. There is also an assumption that the use of the hijab in the Hornbill dance indirectly represents one of the religious values in Islam in that the dance seems to belong to Islam. 
The arguments for the use of the hijab in the Hornbill dance are endless. There will always be debates. According to the researchers, the use of the hijab as the modification of traditional dances is normal. Modifying Hornbill dance but still maintaining the old dance is also a solution. Therefore, there will be two dances, the creative Hornbill dance and the traditional Hornbill dance. Both creative and traditional artists will be satisfied. The creative artists may put the touch of technology in the Hornbill dance and those traditional artists may keep preserving their ancestors' legacy by keep on performing the dance how it was performed in the past.

\section{CONCLUSION}

The development of culture in the postmodern era is inevitable. The use of hijab in the Hornbill dance is a reflection of the development of social religion in the postmodern era. The use of the hijab in the Hornbill dance raises debates. Dancers can still wear hijab in the modified modern Hornbill dance. Both traditional and modern creative artists should be benefited. The creative artists may put the touch of technology in the Hornbill dance and those traditional artists may keep preserving their ancestors' legacy by keep on performing the dance how it was performed in the past.

\section{REFERENCES}

[1] Ruwandari, Endri. Perkembangan Bentuk Penyajian Kanjet Lasan di Desa Ritan Baru Kecamatan Tabang Kabupaten Kutai Kartanegara Kalimantan Timur [Development of Kanjet Lasan Presentation Form in Ritan Baru Village, Tabang District, Kutai Kartanegara Regency, East Kalimantan]. Diss. Fakultas Seni Pertunjukan ISI Yogyakarta, 2019: 6. unpublished

[2] Dewi, Resi Septiana. Keanekaragaman Seni Tari Nusantara [Diversity of Indonesian Dance]. PT Balai Pustaka (Persero), 2012: 1.

[3] Iriani, Zora. Peningkatan Mutu Pembelajaran Seni Tari di Sekolah Dasar [Quality improvement of dance teaching in primary school]. Komposisi: Jurnal Pendidikan Bahasa, Sastra, dan Seni 9.2 (2012): 144. DOI: 10.24036/komposisi.v9i2.98

[4] Riyadi, Agustinus. Postmodernisme vs Modernisme [Postmodernism vs Modernism], Jurnal Studia Philosophica et Theologica, Vol. 4, No. 2 (2004) DOI: doi.org/10.35312/spet. v4i2.126

[5] Fitriani, Annisa. Peran religiusitas dalam meningkatkan psychological well being [The Role of Religiosity in Enhancing the Psychological Well Being]. Al-Adyan: Jurnal Studi Lintas Agama 11.1 (2016): 23.

DOI: https://doi.org/10.24042/ajsla.v11i1.1437
[6] Indriyani, Dian Sri, and Bambang Prihadi. Selfie Art. 3rd International Conference on Arts and Arts Education (ICAAE 2019). Advances in Social Science, Education and Humanities Research, volume 444. Atlantis Press, 2020. DOI: 10.2991/assehr.k.200703.004

[7] Hidayat, Medhy Aginta. Menimbang Teori-Teori Sosial Postmodern: Sejarah, Pemikiran, Kritik Dan Masa Depan Postmodernisme [Considering Postmodern Social Theories: History, Thought, Criticism and the Future of Postmodernism]. Journal of Urban Sociology 2.1 (2019): 43.4 DOI: https://doi.org/10.30742/jus.v2i1.610

[8] Miles, Matthew B., and A. Michael Huberman. Analisis data kualitatif [Qualitative Dara Analysis]. Jakarta: UI Press (1992).

[9] Sari, Endah Nurviana, Busana Pesta Malam Untuk Wanita Dewasa Dengan Sumber Ide Tari Hornbill Dalam Pergelaran Busana Tromgine [Evening Party Dress for Adult Women with Hornbill Dance Ideas Source In The Tromgine Fashion Show], Yogyakarta: UNY, 2019: 1.

[10] Sarie. Melalui Seni, Kita Bersinergi [Through art, we synergize] - Kompasiana.com. KOMPASIANA, $24 \quad$ June 2015, www.kompasiana.com/sarie/552a777ff17e61f110d 623ba/melalui-seni-kita-bersinergi.

[11]David Hogan Jr [@malaysiaasia]. (n.d.). Posts [Instagram profile]. Instagram. Retrevied August 7, 2016 ,

from https://www.instagram.com/p/BIyvvWAhw5Y/ 